\title{
领 New Disease Reports \\ First report of vascular wilt caused by Fusarium proliferatum on chickpea in Cuba
}

\author{
Y. Duarte-Leal ${ }^{1 *}$, B. Martínez-Coca ${ }^{1}$, A. Echevarria-Hernández ${ }^{2}$, E.S. do Carmo de Souza ${ }^{3}$, R.N.G. Miller ${ }^{3}$ and A.C. Café- \\ Filho $^{3}$ \\ ${ }^{1}$ Plant Mycology Laboratory, Phytopathology group, National Center for Animal and Plant Health (CENSA), CP 32700, San \\ José de las Lajas, Mayabeque, Cuba ; ${ }^{2}$ Unit Scientific Technological of Base "Los Palacios", Km 1 1 1/2 road La Francia, Los \\ Palacios, Pinar del Río, Cuba ; ${ }^{3}$ Institute of Biological Sciences, University of Brasilia, Brazil
}

*E-mail: yanisia@censa.edu.cu

Received: 20 Apr 2019. Published: 08 Jun 2020.

Chickpea (Cicer arietinum) is one of the most important legume crops, constituting more than $20 \%$ of grain production worldwide, and providing a significant carbohydrate and protein source for human and animal consumption (Arefian et al., 2014). In Cuba, production still does not meet the demands of the population, making it necessary to import (Echevarria $e t$ al., 2014).The diseases that cause the greatest loss in chickpea yields are root rots, mainly caused by different species of Fusarium, e.g. F. oxysporum f. sp. ciceris.

During the 2014-2015 harvest, field samples of wilting chickpea plants with chlorotic and necrotic roots were taken to the laboratory at the National Center for Animal and Plant Health (CENSA), Mayabeque Province, Cuba. Samples of necrotic roots were surface-sterilised with sodium hypochlorite solution (1\%), and ethanol solution (70\%), rinsed three times with sterile water, air dried, and cultured on potato dextrose agar (PDA, Biocen) plus chloramphenicol $(0.01 \mathrm{~g} / \mathrm{l})$ at $25 \pm 2^{\circ} \mathrm{C}$ for one week. Several fungal colonies were isolated, which were transferred to fresh PDA plates to obtain pure cultures (French \& Hebert, 1982). The aerial mycelium of all samples was initially white but became violet with age (Fig. 1). Macroconidia were slender and to almost straight, with thin walls, apical cell curved, basal cell poorly developed and 3 to 5 -septate. Microconidia were pyriform, 0 -septate, found in false heads, with visible monophialides and polyphialides as described by Leslie \& Summerell (2006) (Fig. 2).

Total genomic DNA was extracted from seven-day-old cultures using the CTAB method. EF1/EF2 primers (O'Donnell et al., 1998) were used in PCR amplification and sequencing of the translation elongation factor 1- $\alpha$ (tef) gene. The sequences were deposited in Genbank (Accession Nos. MT110193, MT110194, MT110195, MT163660 and MT185674). The aligned sequences were analysed for phylogeny (MEGA 7) and BLAST analysis revealed the highest identity (99\%) with Fusarium proliferatum (JF740779). Based on both the culture morphology and DNA sequence analyses, the isolates were identified as Fusarium proliferatum.

To confirm pathogenicity, four seeds were sown in pots $(500 \mathrm{ml})$ containing red ferralitic soil, previously sterilised on two consecutive days $\left(121^{\circ} \mathrm{C} \times 60 \mathrm{~min}\right.$ ). Plants were inoculated in vegetative stage V2 (Toledo, 2018) via root immersion.. A $100 \mathrm{ml}$ of conidial suspension $\left(1 \times 10^{5}\right.$ spores $/ \mathrm{ml}$ ) of each isolate was added to Petri dishes. Roots of the plants were immersed into this conidial suspension for 10 minutes. Sterile water was used for controls. The inoculated plants were subsequently replanted into their original pots and symptom development was checked daily. The symptoms of root rot were observed visually 10 days post-inoculation. Pathogenicity tests were performed twice under the same conditions. Symptoms identical to those of natural infections were observed on all inoculated plants but not on the negative controls. The isolates of $F$. proliferatum were reisolated from the inoculated plants and they were morphologically identical to the original isolate, thus fulfilling Koch's postulates. To our knowledge, this is the first report of Fusarium proliferatum on C. arietinum in Cuba.

\section{Acknowledgements}

The authors would like to thank to Brazilian agency for Coordination of Improvement of Higher Level Personnel (CAPES) for the scholarship granted to the postgraduate student Y. Duarte-Leal in the framework of the Cuba-Brazil collaboration project.

\section{References}

1. Arefian M, Vessal S, Bagheri A, 2014. Biochemical changes in response to salinity in chickpea (Cicer arietinum. L) during early stage of seedling growth. The Journal Animal \& Plant Sciences 24, 1849-1857.

2. Echevarria A, Cruz Triana CA, Deyanira Rivero CRM, Cárdenas RM, Martínez Coca CB, 2014. Comportamiento agronómico de cultivares de garbanzo (Cicer arietinum L.), en condiciones del municipio Los Palacios, Pinar del Río. Cultivos Tropicales 35, 101-106.

3. French ER, Hebert TT, 1982. Métodos de Investigación Fitopatológica. San José, Costa Rica: Instituto Interamericano de Cooperación para la Agricultura.

4. Leslie JF, Summerell BA, 2006. The Fusarium Laboratory Manual. Oxford, UK: Blackwell Publishing Ltd.

5. O'Donnell K, Kistler HC, Cigelnik E, Ploetz RC, 1998. Multiple evolutionary origins of the fungus causing Panama disease of banana: Concordant evidence from nuclear and mitochondrial gene genealogies. Proceedings of the National Academy of Sciences of the United States of America 95, 2044-2049.

http://dx.doi.org/10.1073/pnas.95.5.2044

6. Toledo ER, 2018. Algunos aportes de ecofisiologia de garbanzo (Cicer arietinum L.). https://ansenuza.unc.edu.ar. Accessed 20 April 2020.
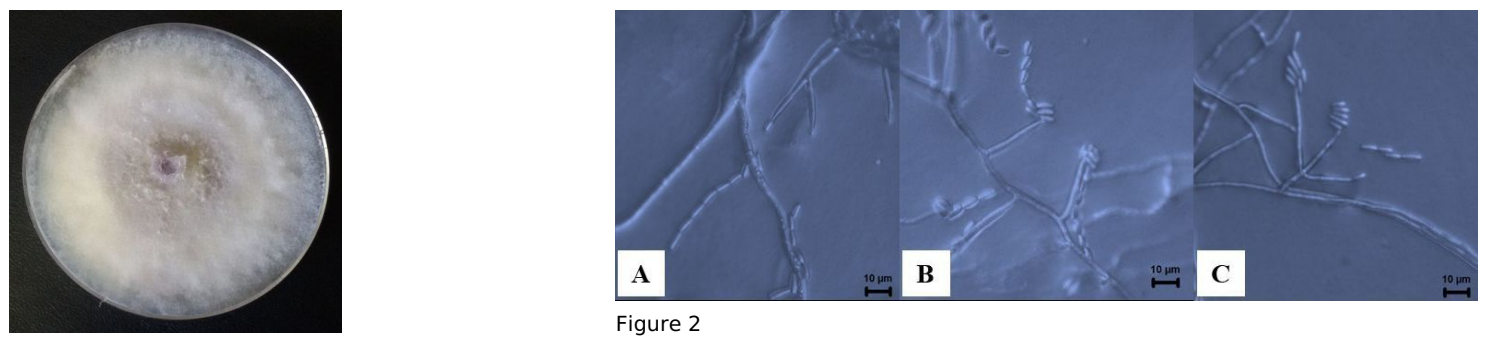

Figure 2

Figure 1

To cite this report: Duarte-Leal Y, Martínez-Coca B, Echevarria-Hernández A, do Carmo de Souza ES, Miller RNG, Café-Filho AC, 2020. First report of vascular wilt caused by Fusarium proliferatum on chickpea in Cuba. New Disease Reports $\mathbf{4 1}, 32$. http://dx.doi.org/10.5197/j.2044-0588.2020.041.032 